\title{
Editorial: The Condition of Refugee: Subjective Experiences and Collective Mobilisations
}

Éditorial : La conditions de réfugiée : expériences subjectives et mobilisations collectives

Editorial: Condición de refugiado: experiencias subjetivas y movilizaciones colectivas

Karen Akoka, Olivier Clochard and Albena Tcholakova

Translator. Katherine Booth and Alexandra Poméon O'Neill

\section{(2) OpenEdition}

\section{Electronic version}

URL: https://journals.openedition.org/remi/14291

DOI: 10.4000/remi. 14291

ISSN: $1777-5418$

This article is a translation of:

Éditorial : La condition de réfugié e : expériences subjectives et mobilisations collectives - URL :

https://journals.openedition.org/remi/8915 [fr]

Publisher

Université de Poitiers

Printed version

Date of publication: 1 December 2017

ISBN: 979-10-90426-60-3

ISSN: 0765-0752

\section{Electronic reference}

Karen Akoka, Olivier Clochard and Albena Tcholakova, "Editorial: The Condition of Refugee: Subjective Experiences and Collective Mobilisations", Revue européenne des migrations internationales [Online], vol. $33-n^{\circ} 4$ | 2017, Online since, connection on 15 April 2022. URL: http://journals.openedition.org/remi/ 14291 ; DOI: https://doi.org/10.4000/remi.14291

This text was automatically generated on 15 April 2022.

(c) Université de Poitiers 


\section{Editorial: The Condition of Refugee: Subjective Experiences and Collective Mobilisations}

Éditorial : La conditions de réfugiée : expériences subjectives et mobilisations

collectives

Editorial: Condición de refugiado: experiencias subjetivas y movilizaciones

colectivas

Karen Akoka, Olivier Clochard and Albena Tcholakova

Translation : Katherine Booth and Alexandra Poméon O'Neill

1 On Wednesday 8 January 2014, a tent surrounded by banners with various slogans was set up in front of the main entrance of the Cypriot Ministry of the Interior in Nicosia (see Photograph 1). Three people who had been recognised as refugees in Cyprus for almost ten years had been on hunger strike for several weeks; they were asking the authorities to grant them rights similar to those of cypriots, to take action against the discrimination they face and in favour of the right to naturalisation. A few days later an oral agreement was reached between the refugees, a UNHCR official and a representative of the Ministry of the Interior, but time passed, and their situation did not change. Six months later, they resumed their hunger strike and again refused to drink water ${ }^{1}$. Given the life-threatening risk faced by these bodies in resistance in the middle of the Cypriot summer, the authorities finally agreed to their demands. 
Photograph 1: Three recognised refugees on hunger strike in front of the main entrance of the Cypriot Ministry of the Interior

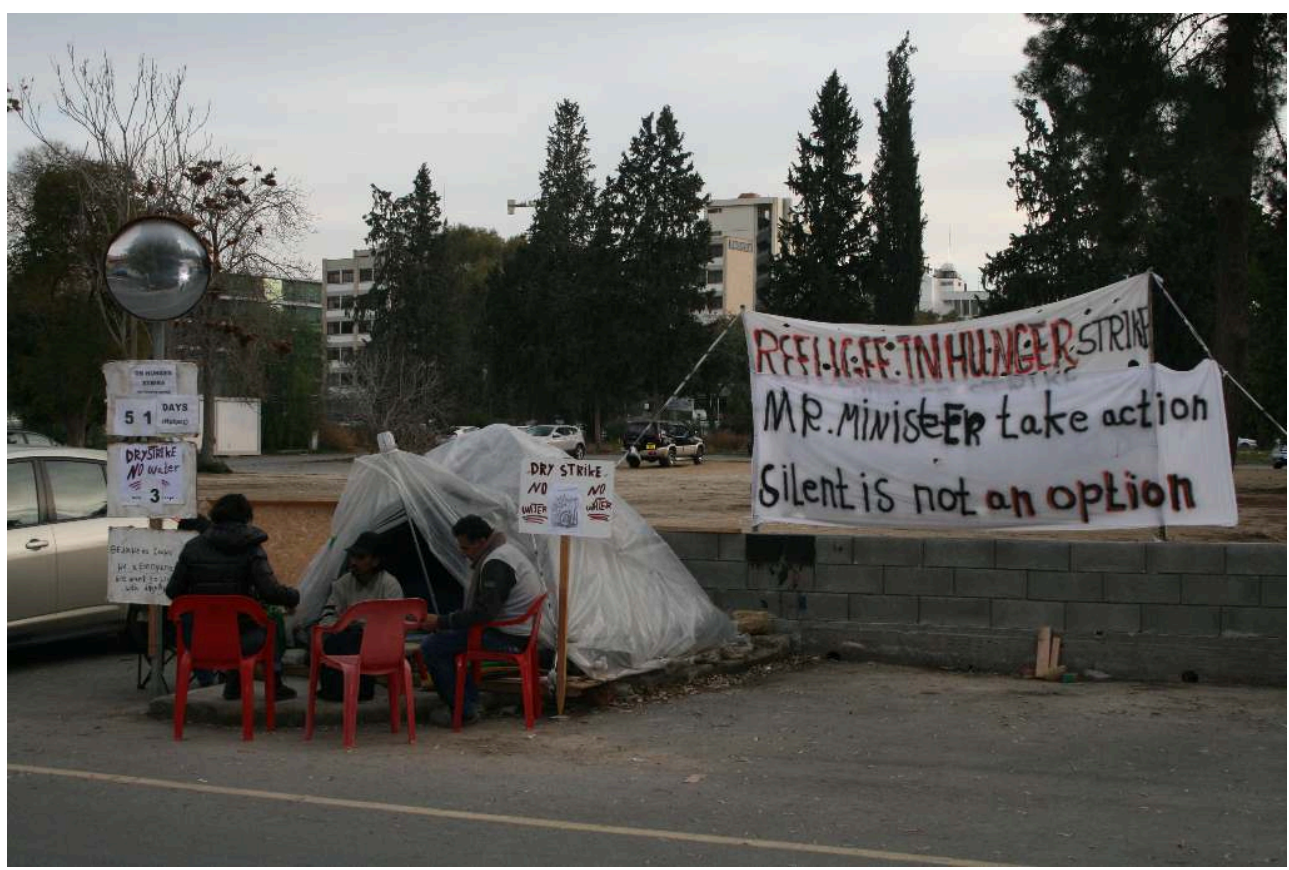

Credit: O. Clochard, Nicosia (Cyprus), 8 January 2014.

2 The view of refugee status as the outcome, even the final destination, of a long and painful process is widespread. However, as shown by the example of the Cypriot refugees mentioned above and by certain scientific, institutional and associative studies $^{2}$, this perception warrants some qualification. Are the difficulties experienced during the months or even years of processing asylum applications really such as to cease with access to a legal status, even when it appears to provide strong protection and to generate rights? What can attention to the difficulties and resources available in the neglected "post-recognition" period teach us about the substance of refugee status? What can the various uses and social experiences of the status tell us about both the individual and collective dimensions of the refugee condition?

3 The various articles in this dossier each answer these questions in their own way, based on different fields, methods and disciplines. Despite the diversity of their approaches, they provide complementary insights into a number of common issues that relate to as many different facets and dimensions of the refugee condition: the subjective experience of status and the individual and collective conditions of its reappropriation or rejection; the resources that it makes it possible to mobilise, whether symbolic (recognition) or material (work) and their limits; the designations to which it opens up and those that it displaces or reproduces.

The editorial of this dossier will first of all show that "recognised refugees" remain neglected figures in research through a review of the art of scientific production on refugees. It will go on to recall the demographic and legal issues concerning the administrative categories of "recognised refugee" at the European level. Finally, we will present the articles in this dossier and the main issues that emerge from their juxtaposition. 


\section{“Recognised refugees": figures neglected by research}

5 From the time of what has been commonly referred to as the "asylum crisis" of the 1990s in Europe, concerns surrounding the topic have become highly visible, as evidenced by the implementation of restrictive policies that are increasingly driven by the imperatives of controlling migratory flows. During the same period, new fields of scientific research on the issue also developed, in particular refugee studies and forced migration studies. For a long time, these two multidisciplinary sub-fields, bringing together lawyers, sociologists, anthropologists, political scientists, economists and geographers, and giving rise to debates in Great Britain, Denmark, Canada and the United States ${ }^{3}$ (Hathaway, 2007; Malkki, 1995; Lassailly-Jacob, 1999; Martin, 1982; Turton, 2003; Castles, 2003a; Fiddian-Qasmiyeh et al., 2014) developed in a compartmentalised way in relation to the field of international migration. In recent years, however, they have come together, giving rise to rich production that allows new topics to be explored, such as the individual, family and collective experiences of confinement, encampment, displacement, return, dispossession and "integration" of asylum seekers, displaced persons and refugees in different geographical contexts (Fiddian-Qasmiyeh, 2014; Bakewell, 2008; Yi Cheung and Phillimore, 2013; Van Hear, 2014). However, most of the analysis developed in refugee/forced migration studies focuses on national and international procedures for determining refugee status and protecting asylum seekers and refugees (Martin, 1982; Boyd, 1999; Goodwin-Gill, 2014), the construction of public policies (Ferris, 1985; Castles, 2003b), the role of international, state and non-governmental institutions in protecting and assisting refugees (Harrell-Bond, 1986) and the "management of undesirables" (Agier, 2008), "humanitarian rationale" and "humanitarian business" (Fassin, 2010; Weiss, 2013), or on the manufacture of policy categories (Turton, 1996; Bakewell, 2008).

6 More specifically, in European countries, which are the subject of the articles in this dossier, academic work on asylum focuses on the genesis, causes and dynamics of situations of exile (Bolzman, 1996; Doraï, 2006; Vahabi, 2008; Vinatier, 2009); the historical processes of institutionalisation of the asylum system (Akoka, 2012, Akoka and Spire, 2013; Angoustures et al, 2017; Masse, 2001; Kobelinsky, 2010) and contemporary asylum policies understood as the production of "undesirables" (Agier, 2002, 2008 and 2011; Clochard, 2007; Valluy, 2009; Migreurop, 2017). The continuous increase in fragility of the status of asylum seeker and the issue of wearing down of social workers have led to a focus on those who accompany asylum seekers (Colin and Laval, 2005). Work combining legal and socio-anthropological approaches study the quest for asylum and the social and legal construction of assistance in accessing the rights of exiles by taking a closer look at the experiences and practices of asylum seekers and social workers (Franguiadakis, Jaillardon and Belkis, 2004; HalluinMabillot, 2012). At the same time, a psychological and psychiatric approach to the mental health of asylum seekers is developing (Bruyère, 2004; Grinberg and Grinberg, 1987; Pestre, 2010; Saglio-Yatzimirsky, 2018). To sum up, legal, monitoring, and exclusion mechanisms and those aimed at managing the waiting period are of interest to researchers, who often take as starting point the need to make visible those that these systems tend to make invisible. These different research perspectives have demonstrated their worth, but they have never focused on the question of the social future of refugees once they have obtained the status. 
7 Among the rarer works that focus directly on recognised refugees, macro perspectives tend to dominate through studies of refugees' access to employment, housing and health in various European states, particularly Great Britain and Sweden (Korac, 2003; Bloch, 2007; Valtonen, 2001; Atfield et al, 2007; Craig et al, 2006; Chang, 2008; Åslund, 2002; Åslund and Fredrikksson, 2005; Kogan, 2003; Lundborg, 2010; Bevelander and Pandakur, 2012; Rea and Wets, 2015). Nevertheless, over the last decade, a number of qualitative research studies on recognised refugees have begun to develop, generally focusing on very specific themes such as the politicisation and political mobilisation of refugees (Dufoix, 2000; Étiemble, 2004); the mental health of refugees (Barou and Blanco, 2011) or access to housing for statutory refugees (Ducheny, 2008). However, it is undoubtedly the issue of labour that accounts for the largest share of the small-scale production on recognised refugees since the socio-historical study by Spire (2004) on refugee labour policies in the period 1945-1975, the research by Billion (2001) and Meslin (2011) on the career paths of refugees from South-East Asia (1970-1980), some of whom have become "workers turned labourers", and the comparative study by Tcholakova (2012) on refugees' search for work in France and Bulgaria.

\section{Refugees in Europe: a contrasting geography of reception and integration policies}

The articles in this dossier are limited to the European area, marked from the interwar period onwards by major movements of people who became stateless in the context of the break-up of great empires, the establishment of new nation-states and large-scale denationalisation. In the face of these situations and within the framework of the League of Nations, the major European states initially set up specific measures according to nationality, as Anouche Kunth's article reminds us in relation to Armenians. After the Second World War, it was within the framework of the United Nations that nineteen States ${ }^{4}$ adopted a system of protection for Europeans based on an individualistic conception of the notion of refugee, the Geneva Convention of 28 July 1951. Sixteen years later, on 31 January 1967, in the context of a Cold War that extended its ideological struggles to the so-called countries of the South, the Additional Protocol adopted in New York broadened the scope of the Geneva Convention to events occurring after 1 July 1951 and to nationals of all States on other continents.

9 Almost seventy years after the adoption of the New York Additional Protocol, and contrary to popular belief, Europe is only host to a small proportion of the world's refugees. According to the UNHCR, by the end of 2016 there will be almost 2 million refugees in the $\mathrm{EU}(0.4 \% \text { of the European population) })^{5}$. These figures would be much higher if European governments applied less restrictive procedures in relation to granting refugee status and refugees' family reunification. In a note published in 2014, Jean-Michel Belorgey, judge at the National Court on the Right to Asylum (Cour Nationale du Droit d'Asile - CNDA) shows that family reunification in France has reached an impasse, notably because "French consulates carry out civil status checks which should not take place or should not be possible in the country of persecution ${ }^{6 "}$. This logic reaches extreme levels in certain European countries, such as Cyprus, where refugees sometimes wait for more than ten years before being able to benefit from family reunification, like the Ivorian man whom we interviewed in 2013, who has been waiting since 2005 for authorisation to bring his children? 

in 2013; $45.5 \%$ in 2017) $)^{8}$, the disparity in national rates thus reveals a picture of the geography of European policies on access to refugee status, further illustrated by the diversity of rights and resources to which it gives rise, raising questions about the very relevance of the common term "refugee" in the various countries of the continent. Although, according to European directives, any person recognised as a "refugee" must be able to benefit from a "a set of uniform rights which are as near as possible to those enjoyed by EU citizens," ${ }^{\prime \prime}$ and although the 1951 Convention itself recalls that in terms of education, assistance, social security and employment, "States shall accord to refugees the same treatment as is accorded to nationals," access to these rights continues to be the subject of tension and remains highly disparate across different European countries.

11 In Italy, where the annual rates of recognition (refugee status, subsidiary protection and humanitarian status) are sometimes higher than the European average (48.1\% of favourable decisions at first instance in $2008,60.1 \%$ in $2013,40.6 \%$ in 2017) ${ }^{10}$ it is above all, in the words of a UNHCR spokesperson, "what comes after that is not satisfactory", such as the lack of a fixed income and the inability to find stable employment ${ }^{11}$. Nils Muiznieks, Commissioner for Human Rights, emphasises for his part "the near absence of an integration framework" ${ }^{12}$ for refugees in Italy. The CFDA report (2008: 100) had already drawn attention to these points in 2008 by pointing out the high number of Eritreans who had obtained subsidiary protection in Italy, yet present in the "jungles" of the Calais region, waiting to reach Great Britain. from one European country to another. Beneficiaries under the Geneva Convention are entitled to a ten-year residence permit in France and a five-year residence permit in Spain or Italy ${ }^{13}$ (automatically renewable in both cases). In Cyprus, this period is reduced to three years, as is the case in Romania, where recognised refugees must prove that they reside in the country by means of a property title or rental contract in order to obtain their residence card ${ }^{14}$.

13 The right of refugees to settle in a country other than that in which they have received protection also varies from country to country. Although the European Union amended the 2003 Directive on the status of "long-term" residents in 2011 to allow statutory refugees to be granted status, significant disparities remain. For example, a refugee recognised in France can settle in Belgium, which is not the case for a refugee recognised in Cyprus or Bulgaria. Since the three-year residence permit issued to refugees by the Cypriot and Bulgarian authorities is not considered to be a "long-term" residence permit by the European Union, its beneficiaries can move around, but not settle elsewhere in Europe.

14 Since the Treaty of Amsterdam (1999), Member States have repeatedly reiterated their commitment to establish a Common European Asylum System, including "the establishment of a uniform refugee status valid throughout the Union", a promise reaffirmed in December 2009, at the time of the adoption of the Stockholm Programme, when the European Council stressed "the objective of establishing a common area of protection and solidarity based on a common asylum procedure and a uniform status for those granted international protection". However, European asylum policy continues to be marked by the juxtaposition of national systems rather than by harmonisation, despite the adoption of directives which regularly recall that "such a 
policy should be governed by the principle of solidarity, including financial solidarity, between Member States". Behind this litany of good intentions, it is clear not only that European asylum policy has moved from the protection of refugees to protection against the arrival of asylum seekers, to use the expression adopted by BouteilletPaquet (2001), but that the continuous increase in fragility of the status has given rise to disparate social experiences of the condition of refugee.

\section{The condition of refugee: uses and experiences post recognition}

15 This dossier aims to look at the period that follows the granting of refugee status, which is often seen as an end result. While it is true that, at the subjective level of the individual, obtaining such status represents a milestone shedding light on processes of bureaucratic, legal and administrative categorisation and designations, the "post recognition" period is no less interesting. This is demonstrated by the various articles in this dossier, each in their own way.

16 Anouche Kunth focuses on the interwar period, looking at the relationship of the first refugees to their status and the administrations that managed it. She examines the concrete realities of this status marked by practical and legal vagueness. Through this approach, the author traces the way in which the refugees themselves, and in particular Armenian refugees, understood the scope of this administrative category, a category which they appropriated in order to transform it into a group to which they belong. Using the category as a starting point is the author's way of grasping the relations between subjects and power mechanisms, but also of grasping subjectivities in their personal relationship to a status they reject or claim.

Karine Meslin analyses the social effects of being designated as a refugee on the basis of research into Cambodians recognised as refugees in the 1980s who settled in the Pays de la Loire region. The long duration of their presence in France (thirty years) enables the author to provide a longitudinal analysis that includes second generations. It shows the elders' persistent efforts to stick to the representations of refugees in general (seen as foreigners with strong socio-cultural resources) and Cambodian refugees in particular (seen as docile and integrated foreigners). This effort involves distancing themselves from the social figure of the immigrant and the negative prejudices that arise from it. This is done by using administrative categories and ethnic stereotypes.

Barbara Herman and Andréa Rea propose a statistical study of the labour market integration of refugees in Belgium based on longitudinal administrative data and the concept of "migratory career". They show that time is the main factor in moving away from welfare dependency, entering the labour market and changing socio-economic position. Beyond the time factor, the authors highlight three other major determinants of the socio-economic integration of refugees: structural conditions (institutional and political), individual characteristics (age, gender, family situation and nationality) and the mobilisation of social networks. Contrary to stereotypes, they show that subSaharan refugees are most likely to have an "active career" in Belgium, putting forward the hypothesis of the French language (spoken by a significant number of them) as a key factor in this success. Finally, they show the relative effects of being recognised as a refugee in socio-economic terms, since obtaining this status tends to consolidate the situation of people who were already well integrated into the labour market before 
being recognised as refugees. In the same vein, the acquisition of the status leads to a significant shift in sectors of activity (from agriculture to industry, public administration, health, social, accommodation, catering and trade) for those already in employment. From the point of view of labour market integration, it thus appears that the recognition of refugee status reinforces a previous position rather than pushing people into a new condition.

Angelina Étiemble proposes a reflection on processes of politicisation of Tamil refugees, the largest refugee population in France since the end of the 1990s, and on refugee status as a vector for collective mobilisation. Her article shows, based on an ethnographic survey of La Chapelle district in Paris, that politicisation operates in the shadow of the Tamil national liberation movement (LTTE), known as the "Tigers", which uses refugee status as a resource for recognition of its cause. The daily life of Tamil refugees, but also their projects and the meaning given to their exile are thus framed by Tamil militants. The latter promote an "official historiography" and a nationalist interpretation of exile which must be entirely devoted to supporting the "Tamil cause". In this context, the term "refugee" or "exile", which gives recognition to the Tamil struggle in Sri Lanka, is valued over that of the "diaspora"; plans to immigrate to Great Britain are criticised as a former colonial power hostile to the Tamil cause; and naturalisations are encouraged as a means of legitimising the cause on the French scene. This framing of identity, the promotion of a Tamil way of life in exile and the organisation of a community life directed towards sacrifice for the collective project of the "Tamil people", is largely carried out through the associations in La Chapelle district, which combine political, humanitarian and cultural dimensions in order to ensure the adherence of Tamils to their cause. With the banning of LTTE in Europe (2006) and their defeat in Sri Lanka (2009), this hold is weakening; associative and religious activities are more oriented towards cultural and linguistic links than towards the political project alone; the term "diaspora" is revalued as is Tamil ethnicity without a nationalist substratum.

Albena Tcholakova focuses on the refugee condition in Bulgaria, a country in a specific situation compared to most of the major European and Mediterranean states, as a land of emigration and recent immigration. She looks at the experience of refugee status in this particular context through the prism of work. This entry point allows her to shed light on the social and symbolic experience of refugee status by revealing the distortions between, on the one hand, the harshness of the Bulgarian context in terms of access to rights and work and, on the other, refugees' expectations of access to social and political citizenship. Work as a social, institutional and economic space is explored as an expression and activation of protean domination (gender, class, race, etc.), but also as a space for self-rehabilitation, for oneself and in relation to others. The author shows the social relations of domination at play and the way in which work contributes to the reinforcement of gender and ethnicization norms that encumber refugees and from which their new status makes it difficult for them to escape.

\section{From subjective identities to collective mobilisations}

21 Based on fieldwork (France, Bulgaria, Belgium), groups (Armenians, Africans, Cambodians, Tamils), methods (historical, ethnographic and quantitative surveys) and taking into account very different periods and temporalities, these studies show several 
major points of convergence which serve as sources of insight and avenues for further reflection on the condition and social experience of refugees.

Paying attention to the "post recognition" period makes it possible first of all to extend work on deconstructing refugee status by including an additional stage, in the wake of a long line of work on the status (Harrell Bond; 1986, Malkki, 1995; Noiriel, 1998; Halluin-Mabillot, 2012) understood above all as a social construction, but also as the product of considerations (political, diplomatic and socio-economic) that say more about societies that label, than those who are designated as refugees (Akoka, 2012). Attention to the "post recognition" period shows that the refugee status can be understood, certainly as a "product", but also from the point of view of its effects. From this point of view, the diversity of rights and the heterogeneity of the condition of refugee contribute to the work of deconstructing the status and provide valuable insights into the societies that (re)shape it. It is in this sense that the decision to look at the "post recognition" period in very diverse national, political, social and historical configurations has proved heuristic. It has made it possible to flesh out the heterogeneity of rights, effects, conditions and experiences revealed between Armenian, Cambodian or Tamil refugees recognised in France respectively in the interwar period, the late 1970s and the years 1990-2000; or refugees recognised in the decade since 2010 in Belgium or Bulgaria.

The analysis of the "post recognition" period also opens the eye to a longer, and in a sense more existential, period than that of preparation and waiting for a verdict from the outside. Once refugee status has been obtained, it is a question of making (or not making) this new legal-administrative identity one's own. How do the persons concerned respond to these administrative classifications? How do they appropriate the "paper identities" assigned to them? How do they inhabit them or keep them at a distance and under what conditions? Combining the question of experience with that of designation makes it possible to break with a somewhat dichotomous division of sociological study between, on the one hand, the analysis of social categories as identities imposed from the outside and, on the other hand, that of social groups as the outcome of a construction effort by and for its members (Boltanski, 1982; Noiriel, 1997; Tcholakova, 2016).

Unsurprisingly, the question of the "post recognition" period leads to the issue of labour in a significant number of the articles assembled here. Karine Meslin shows that the positive prejudices from which Cambodian refugees benefit even before they come into contact with their employers or colleagues have, since the 1980s, facilitated their professional integration, yet without avoiding social downgrading, since the great majority of them are semi-skilled workers or employees. Barbara Herman and Andréa Rea highlight some key factors in the integration of refugees into the labour market in Belgium today, first and foremost the length of time they have been in the country. Albena Tcholakova shows ambivalence about work experience among refugees in Bulgaria, a source of income, emancipation, a space for building positive sociability and self-image on the one hand, and on the other, a place of stigma reducing refugees to a worker's body (mere workforce) and a racialised body. Anouche Kunth shows that, in the absence of a refugee category which today carries a stable and consolidated set of rights, it is as workers (in the Schneider factories) that the Armenians of Le Creusot, who do not yet know that they are entitled to refugee status, have access to assistance. 
Finally, refugee status appears in a number of articles in this dossier as a tool for various forms of collective mobilisation. Karine Meslin shows the use by Cambodian refugees of the refugee status as a collective sign of distinction to differentiate the whole group from the social figure of the immigrant and the negative stereotypes associated with it. However, this effort to distinguish themselves comes at the price of symbolic violence, in particular against the most working-class fractions and second generations, who are more resistant to the collective injunction for hypercorrection. In the case of Armenian refugees from the interwar period in France, studied by Anouche Kunth, the collective dimension is all the more important since refugee status does not yet have an individual dimension and it is on the basis of belonging to the national group (in this case that of the Armenians) that refugee status is granted. Angélina Étiemble shows that refugee status is invested by activists and sympathisers of Tamil separatist movements in France as the vector of strong recognition for their cause. From then on, a powerful framing effort and strong pressure are exerted on members of the group to promote the idea of collective belonging to the Tamil refugee community centred on an unwavering attachment to the country and the cause, as opposed to identification with the Tamil diaspora which gives greater value to bonds of solidarity within the diaspora community.

\section{BIBLIOGRAPHY}

Agier Michel (2011) Le Couloir des exilés. Être étranger dans un monde commun, Bellecombe-en-Bauge, Éditions du Croquant, $120 \mathrm{p}$.

Agier Michel (2008) Gérer les indésirables. Des camps de réfugiés au gouvernement humanitaire, Paris, Flammarion, $350 \mathrm{p}$.

Agier Michel (2002) Aux abords du monde, les réfugiés, Paris, Payot \& Rivages, 155 p.

Akoka Karen (2012) La fabrique du réfugié à l'OFPRA (1952-1992) : du consulat des réfugiés à l'administration des demandeurs d'asile, Thèse de doctorat en Sciences Sociales, Université de Poitiers, $519 \mathrm{p}$.

Akoka Karen et Spire Alexis (2013) Pour une histoire sociale de l'asile politique en France, Pouvoirs, Revue française d'études constitutionnelles et politiques, 144, pp. 67-77.

Angoustures Aline, Kevonian Dzovinar et Mouradian Claire (2017) Réfugiés et apatrides, administrer l'asile en France (1920-1960), Presses Universitaires de Rennes, 312 p.

Åslund Olof (2002) Integration of refugees in the Swedish labor market - policies and neighborhoods, Working Paper, Uppsala, Instute for Labour Market Policy Evaluation.

Åslund Olof and Fredrikksson Peter (2005) Ethnic enclaves and welfare cultures - quasi experimental evidence, Working paper, 8, Uppsala, Instute for Labour Market Policy Evaluation.

Atfield Gaby, Brahmbhatt Kavita and O'Tool Therese (2007) Refugees' Experiences of Integration, Birmingham, Refugee Council and University of Birmingham, 76 p. 
Bakewell Oliver (2008) Research beyond the Categories: The Importance of Policy Irrelevant Research into Forced Migration, Journal of Refugee Studies, 4 (21), pp. 432-453.

Barou Jacques et Blanco Domitille (2011) Parcours de réfugiés : le statut, et après ? Étude anthropologique menée auprès de réfugiés de l'agglomération lyonnaise, Réseau Samdarra.

Bevelander Pieter (2011) The employment integration of resettled refugees, asylum claimants, and family reunion migrants in Sweden, Refugee Survey Quarterly, 30 (1), pp. 22-43.

Bevelander Pieter and Pendakur Ravi (2012) The Labour Market Integration of Refugee and Family Reunion Immigrants: A Comparison of Outcomes in Canada and Sweden, IZA Discussion Paper, 6924, 27 p.

Billion Pierre (2001) Où sont passés les « travailleurs réfugiés » ? Trajectoires professionnelles des populations du Sud-Est asiatique, Hommes et Migrations, 1234, pp. 38-49.

Bloch Alice (2007) Refugees in the UK labour market: The conflict between economic integration and policy-led labour market restriction, Journal of Social Policy, 37 (1), pp. 21-36.

Boltanski Luc (1982) Les cadres. La formation d'un groupe social, Éditions de Minuit, 528 p.

Bolzman Claudio (2001) Politiques d'asile et trajectoires sociales des réfugiés : une exclusion programmée. Le cas de la Suisse, Sociologie et Sociétés, 33 (2), pp. 133-158.

Bolzman Claudio (1996) Sociologie de l'exil : une approche dynamique. L'exemple des réfugiés chiliens en Suisse, Zürich, Seismo, 333 p.

Bouteillet-Paquet Daphné (2001) L'Europe et le droit d'asile, Paris/Montréal/Budapest/Turin, L'Harmattan, 396 p.

Boyd Monica (1999) Gender, Refugee Status and Permanent Settlement, Gender Issues, 1 (17), pp. 5-25.

Bruyère Blandine (2004) Le demandeur d'asile : objet du tortionnaire, sujet du travail psychothérapique, Le journal des psychologues, 217, pp. 41-43.

Castles Stephen (2003a) Toward a Sociology of Forced Migration and Social Transformation, Sociology, 77 (1), pp. 13-34.

Castles Stephen (2003b) The International Politics of Forced Migration, Socialist Register, 39, pp. 172-192.

Chang Jaclyn (2008) Beyond 365 Days. The Economic Integration of African Refugees in Vancouver, Canada, Dissertation in fulfilment of the requirements for the degree Masters in Forced Migration Studies, Faculty of Arts, University of the Witwatersrand, $111 \mathrm{p}$.

Clochard Olivier (2007) Le jeu des frontières dans l'accès au statut de réfugié. Une géographie des politiques d'asile et d'immigration, Thèse de doctorat en géographie, Université de Poitiers, $486 \mathrm{p}$.

Colin Valérie et Laval Christian (2005) Santé mentale et demandeurs d'asile en Région Rhône-Alpes. Modalités pratiques et inter partenariales, Rapport final, Recherche-action commanditée par la DRASS Rhône-Alpes, ORSPERE-ONSMP, 178 p.

Coordination Française pour le Droit d'Asile (CFDA) (2008) La loi des jungles. La situation des exilés sur le littoral de la Manche et la Mer du Nord, Rapport coordonné par Karen Akoka et Olivier Clochard, 156 p., [en ligne]. URL : http://cfda.rezo.net/download/ La\%20loi\%20de\%20la\%20jungle_12-09-2008.pdf 
Craig Louise, Goodson Lisa, Phillimore Jenny and Sankey Sian (2006) Employability Initiatives for Refugees in Europe: Looking at, and Learning from, Good Practice, Report for EQUAL and the Home Office, The Centre for Urban and Regional Studies, The University of Birmingham, Edgbason.

Doraï Kamel (2010) Les Irakiens en Suède : exil et recomposition migratoire depuis la chute du régime de Saddam Hussein en 2003, e-migrinter, 5, pp. 13-23, [en ligne]. URL : http:// migrinter.labo.univ-poitiers.fr/e-migrinter2010_05_tout/

Doraï Kamel (2006) Les réfugiés palestiniens du Liban : une géographie de l'exil, Paris, CNRS Éditions, $256 \mathrm{p}$.

Ducheny Marie (2008) Le dispositif national d'accueil et l'accès au logement : enquête sur les relations entre l'État et les réfugiés statutaires, Thèse de doctorat en sociologie, Université Paris 5, 407 p.

Dufoix Stéphane (2000) Fausses évidences. Statut de réfugié et politisation, Revue Européenne de Migrations Internationales, 16 (3), pp. 147-164, [en ligne]. URL : http://www.persee.fr/doc/ remi_0765-0752_2000_num_16_3_1745

Étiemble Angélina (2004) Les Tamouls du Sri Lanka dans la région parisienne. L'emprise du politique, Revue Française des Affaires sociales, 2, pp. 145-164.

Fassin Didier (2010) La raison humanitaire. Une histoire morale du temps présent, Paris, Le Seuil, 368 p.

Ferris Elizabeth G. (Ed.) (1985) Refugees and World Politics, New York, Praeger Publishers Inc, 240 p. Fiddian-Qasmiyeh Elena (2014) Gender and Forced Migration, in Elena Fiddian-Qasmiyeh, Gil Loescher, Katy Long and Nando Sigona Eds., The Handbook of Refugee and Forced Migration Studies, Oxford, Oxford University Press, pp. 395-408.

Fiddian-Qasmiyeh Elena, Loescher Gil, Long Katy and Sigona Nando (Eds.) (2014) The Handbook of Refugee and Forced Migration Studies, Oxford, Oxford University Press, 776 p.

Franguiadakis Spyros, Jaillardon Edith et Belkis Dominique (2004) En quête d'asile. Aide associative et accès $a u(x)$ droit(s), Paris, LGDJ, $287 \mathrm{p}$.

Goodwin-Gill Guy S. (2014) The international Law of Refugee Protection, in Elena FiddianQasmiyeh, Gil Loescher, Katy Long and Nando Sigona Eds., The Handbook of Refugee and Forced Migration Studies, Oxford, Oxford University Press, pp. 36-47.

Grinberg Léon et Grinberg Rebeca (1987) Psychanalyse du migrant et de l'exilé, Lyon, CLE, 289 p. Hachimi Alaoui Myriam (2007) Les Chemins de l'exil. Les Algériens exilés en France et au Canada depuis les années 1990, Paris, L'Harmattan, 202 p.

Halluin-Mabillot Estelle (d') (2012) Les épreuves de l'asile. Associations et réfugiés face aux politiques du soupçon, Paris, EHESS, $301 \mathrm{p}$.

Harrell-Bond Barbara E. (1986) Imposing Aid: Emergency Assistance to Refugees, Oxford, Oxford University Press, $440 \mathrm{p}$.

Hathaway James C. (2007) Forced Migration Studies: Could we Agree just to "Date"?, Journal of Refugee Studies, 3 (20), pp. 349-369.

Kobelinsky Carolina (2010) L'accueil des demandeurs d'asile. Une ethnographie de l'attente, Paris, Édition du Cygne, 269 p.

Kogan Irena (2003) Ex-Yugoslavs in the Austrian and Swedish labor markets: The significance of period of migration and the effect of citizenship acquisition, Journal of Ethnic and Migration Studies, 29, pp. 595-622. 
Korac Maja (2003) Integration and How We Facilitate It: A comparative Study of the Settlement Experiences of Refugees in Italy and the Netherlands, Sociology, 37 (1), pp. 51-68.

Lassailly-Jacob Véronique (1999) Migrants malgré eux : une proposition de typologie, in Véronique Lassailly-Jacob, Jean-Yves Marchal et André Quesnel Éds., Déplacés et réfugiés : la mobilité sous contrainte, Paris, IRD, pp. 27-48.

Lundborg Per (2010) Refugees' integration: Lagging Wages or Lagging employment?, Working paper, 2, Stockholm, CEIFO, $29 \mathrm{p}$.

Malkki Liisa H. (1995) Refugees and Exile: From "Refugee Studies" to the National Order of Things, Annual Review of Anthropology, 24, pp. 495-523.

Martin David A. (1982) Large-Scale Migrations of Asylum Seekers, American Journal of International Law, 76, pp. 598-605.

Masse Jean-Pierre (2001) Genèse et institutionnalisation du dispositif d'accueil des réfugiés politiques en France, Les cahiers de la sécurité intérieure, 45, pp. 45-68.

Meslin Karine (2011) Les réfugiés cambodgiens, des ouvriers dociles ? Genèse et modes de pérennisation d'un stéréotype en migration, Revue Européenne des Migrations Internationales, 27 (3), pp. 83-101, [en ligne]. URL : https://journals.openedition.org/remi/5646

Migreurop (2017) Atlas des migrants en Europe. Approches critiques des politiques migratoires, Paris, Armand Colin, $176 \mathrm{p}$.

Noiriel Gérard (1998) Réfugiés et sans papiers : la République face au droit d'asile, XIXe-XXe siècle, Paris, Hachette Littérature, 355 p.

Noiriel Gérard (1997) Représentation nationale et catégories sociales. L'exemple des réfugiés politiques, Genèses, 26, pp. 25-54.

Pestre Élise (2010) La vie psychique des réfugiés, Paris, Payot et Rivages, 377 p.

Rea Andrea and Wets Johan (Eds.) (2015) The Long and Winding Road to Employment. An Analysis of the Labour Market Careers of Asylum Seekers and Refugees in Belgium, Gand, Academia Press, 186 p. [online]. URL: http://www.myria.be/files/Careers_LR.pdf

Saglio-Yatzimirsky Marie-Caroline (2018) La voix de ceux qui crient. Rencontre avec des demandeurs d'asile, Paris, Albin Michel, 318 p.

Spire Alexis (2004) Les réfugiés, une main-d'œuvre à part ? Conditions de séjour et d'emploi, France, 1945-1975, Revue Européenne des Migrations Internationales, 20 (2), pp. 13-38, [en ligne]. URL : https://journals.openedition.org/remi/963

Tcholakova Albena (2016) Le remaniement identitaire entre reconnaissance et maintien de la cohérence biographique. L'exemple des réfugié·e·s en France, Sociologie, 7 (1), pp. 59-76.

Tcholakova Albena (2012) En quête de travail, enjeux de reconnaissance et remaniement identitaire: approche comparée France-Bulgarie de carrières professionnelles de réfugiés, Thèse de doctorat en sociologie et en sciences politiques (cotutelle de thèse avec la Nouvelle Université Bulgare), Université Lumière Lyon 2, 457 p.

Turton David (2003) Conceptualising Forced Migration, RSC Working Paper, Refugee Studies Centre, University of Oxford, 2, pp. 1-19.

Turton David (1996) Migrants and Refugees: a Mursi case study, in Allen Tim Ed., In Search of Cool Ground: War, Flight, and Homecoming in Northeast Africa, Trenton, Africa Word Press, pp. 96-110. 
United Nation Hight Commissioner for Refugees (UNHCR) (2013a) A new beginning. Refugees Integration in Europe, UNHCR, 146 p.

United Nation Hight Commissioner for Refugees (UNHCR) (2013b) Vers un nouveau départ: l'intégration des réfugiés en France, UNHCR, 92 p.

Vabre Frédéric (2004) L'engagement comme ressource facilitant l'intégration. Le cas des réfugiés latino-américains en Suède, Revue Européenne des Migrations Internationales, 20 (2), pp. 187-194, [en ligne]. URL : https://journals.openedition.org/remi/990

Vahabi Nader (2008) Sociologie d'une mémoire déchirée. Le cas des exilés iraniens, Paris, L'Harmattan, $246 \mathrm{p}$.

Valluy Jérôme (2009) Rejet des exilés. Le grand retournement du droit de l'asile, Éditions du Croquant, $382 \mathrm{p}$.

Valtonen Kathleen (2001) Social work with immigrants and refugees: developing a particiaptionbased framework for anti-opressive practice, British Journal of Social Work, 31, pp. 955-960.

Van Hear Nicholas (2014) Refugees, Diasporas and Transnationalism, in Elena Fiddian-Qasmiyeh, Gil Loescher, Katy Long and Nando Sigona Eds., The Handbook of Refugee and Forced Migration Studies, Oxford, Oxford University Press, pp. 176-187.

Vinatier Laurent (2009) Un modèle de parcours migratoire : Le cas des réfugiés tchétchènes en Europe, EurOrient, 29, pp. 67-90.

Weiss Thomas G. (2013) Humanitarian Business, Cambridge, UK Polity Press, 200 p.

Yi Cheung Sin and Phillimore Jenny (2013) Social networks, social capital and refugee integration, Research Report for Nuffield Foundation, $54 \mathrm{p}$.

\section{NOTES}

1. For more details, see the letter dated 10 June 2014 by the three protagonists, "Letter of recognized refugees to UNHCR Representative for Southern Europe", [online]. URL: https:// kisa.org.cy/10-06-2014-letter-of-recognized-refugees-to-unhcr-representative-for-southerneurope/

2. In France, the websites run by the associations Forum Réfugiés and France Terre d'Asile have presentations of the AccelAir refugee integration programme and the activities of the Observatoire de l'intégration des réfugiés (Refugee Integration Observatory) respectively. UNHCR publications (2013a and 2013b) focus on the integration of these populations into host societies in European countries, with particular attention paid to accommodation measures. See also the work carried out by the association Singa France in supporting refugees (particularly in relation to business development initiatives).

3. The Refugee Studies Centre at the University of Oxford plays a leading role. See also the work developed at York University in Toronto and the Refugee Policy Group in Washington DC, to mention just a few of the academic centres.

4. Austria, Belgium, Brazil, Colombia, Denmark, France, Germany, Greece, Israel, Italy, Liechtenstein, Luxembourg, Netherlands, Norway, United Kingdom, Holy See, Sweden, Switzerland and Turkey.

5. It should be recalled that, according to the UNHCR, the number of people uprooted throughout the world as a result of conflict and persecution amounted to 65.6 million at the end of 2016. The number of refugees is estimated at nearly 22.5 million (i.e. people who have crossed an international border) and the number of displaced persons at nearly 40.3 million (i.e. people who 
have found refuge inside their country). In addition to these, there are an estimated 5.3 million Palestinian refugees under UNWRA's mandate.

6. Belorgey Jean-Michel, Le droit d'asile, bouc émissaire des anti immigrationnistes, 28 April 2014, [online]. URL: http://ecritures-et-societe.over-blog.com/article-le-droit-d-asile-bouc-emissairedes-anti-immigrationnistes-123462508.html

7. Field notes (January 2014) from interviews in Cyprus by Karen Akoka and Olivier Clochard.

8. Decisions made at first instance (source: Eurostat database consulted in June 2018).

9. European Parliament, Tampere European Council, 15 and 16 October 1999, [online]. URL: https:// www.europarl.europa.eu/summits/tam_en.htm

10. Figures extracted in May 2018 from the Eurostat database.

11. Laura Boldrini, UNHCR spokesperson in Italy, in a New York Times article dated 21 December 2012 by Élisabetta Povoledo, “The Italian Paradox on Refugees”.

12. Commissioner on Human Rights, 18 September 2012, "Italy needs to speed up court proceedings and improve the treatment of Roma and migrants".

13. Source: interview with Alessandra Capodanno, Migreurop, 11 February 2014.

14. The website of the General Inspectorate for Immigration states that foreigners who have obtained a form of protection from the Romanian State can obtain a residence permit to prove their identity and leave the country. In order to apply for this, they must provide evidence that their residence is in Romania (title deed, rental contract registered with the tax administration, authenticated accommodation certificate or any valid document from the Romanian administration that proves payment of an allowance).

INDEX

Keywords: recognised refugees, experiences and social practices, mobilisation Palabras claves: refugiados reconocidos, experiencias y prácticas sociales, movilizaciones Mots-clés: réfugiés reconnus, expériences et usages sociaux, mobilisations

\section{AUTHORS}

\section{KAREN AKOKA}

Sociologist, Lecturer in political science, University of Paris-Nanterre, Institut des Sciences sociales $d u$ Politique (Institute for Social Sciences of Politics - ISP), Maison Max Weber, $3^{\text {rd }}$ floor, 200 avenue de la République, 92001 Nanterre Cedex; k.akoka@parisnanterre.fr

\section{OLIVIER CLOCHARD}

Geographer, Research Fellow at the CNRS (Centre national de la recherche scientifique - French National Centre for Scientific Research), University of Poitiers, MIGRINTER, MSHS, A5 Building, 5 rue Théodore Lefebvre, TSA 21103, 86073 Poitiers cedex 9; olivier.clochard@univ-poitiers.fr

\section{ALBENA TCHOLAKOVA}

Sociologist, Lecturer, University of Lorraine, Longwy IUT (University Institutes of Technology), 186 rue de Lorraine, 54400 Cosnes-et-Romain; albena.tcholakova@univ-lorraine.fr 